\title{
Sustainable Management of Sundarbans: Stakeholder Attitudes Towards Participatory Management and Conservation of Mangrove Forests
}

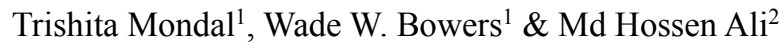 \\ ${ }^{1}$ School of Science and the Environment/Environmental Policy Institute, Grenfell Campus, Memorial University \\ of Newfoundland, Corner Brook, NL A2H 5G5, Canada \\ ${ }^{2}$ School of Natural Resources, College of the North Atlantic, Corner Brook, NL A2H 6H6, Canada \\ Correspondence: Trishita Mondal, Environmental Policy Institute, Grenfell Campus, Memorial University of \\ Newfoundland, Corner Brook, NL A2H 5G5, Canada. Tel: 519-820-2718. E-mail: tmondal@grenfell.mun.ca
}

\author{
Received: February 27, $2021 \quad$ Accepted: March 23, $2021 \quad$ Online Published: March 25, 2021 \\ doi:10.5539/jsd.v14n3p23 URL: https://doi.org/10.5539/jsd.v14n3p23
}

\begin{abstract}
The Sundarbans is one of the oldest, contiguous, and systematically managed mangroves in the world. This biologically diverse ecosystem provides numerous benefits and services to local communities and the environment, however, it continues to remain under threat from population pressure, overexploitation, natural disasters and lack of practical policy regimes. This study assesses attitudes of local stakeholders towards sustainable management and conservation of mangrove forests as a means to assist planners, policy-makers, and decision-makers. A mixedmethod approach was conducted to fulfill the objectives of this study. The study reveals that the people of the Sundarbans Impact Zone are highly dependent on the Sundarbans for their livelihood. Indeed, collecting resources from both aquatic and terrestrial areas is considered a traditional right. As such, people are increasingly becoming more conscious about government policy, and they want the forest to be managed sustainably. Generally, the language of governance is very strong, but many argue that implementation of policy is difficult because of competing policies, weak infrastructure, inefficiencies, illegal approaches, and corruption. Efforts should be made to develop and advance coupled human-environment (socio-ecological) systems that call for more participatory management approaches. Wider participation and 'empowerment' of stakeholders would improve the governance of the Sundarbans and ensure common priorities and levels of agreement on both conservation and livelihood issues.
\end{abstract}

Keywords: Sundarbans, mangrove conservation, sustainable forest management, participatory approach, forest policy.

\section{Introduction}

The Sundarbans represent a cluster of low-lying islands in the Bay of Bengal spread across Bangladesh and the West Bengal region of India (Figure 1). This region, encompassing the world's largest contiguous mangrove forest, covers 1000000 ha in the Ganges delta of India and Bangladesh (Hussain and Acharya 1994; Roy 2016). The Bangladesh part of the Sundarbans (62\% of the Sundarbans) (Figure 1) is recognized for its rich biodiversity of both flora and fauna representing thousands of species of plants, fishes, birds, crustaceans, reptiles and mammals, including the endangered Royal Bengal tiger (Panthera tigris tigris) (Kamruzzaman et al., 2018; Haque and Reza, 2017; Abdullah et al., 2016; Payo et al., 2016). Worldwide, a number of researchers (Mozumder et al., 2018; Islam et al., 2018; Isbell et al., 2017; Abdullah et al., 2016) have documented the economic, social and environmental benefits of mangroves to forest-dependent communities (FDCs). Approximately 3.5 million people of 17 adjacent subdistricts of the Sundarbans are critically dependent on the mangrove forest for their livelihood. These areas are collectively known as Sundarbans Impact Zone (SIZ) (Roy et al., 2013). 


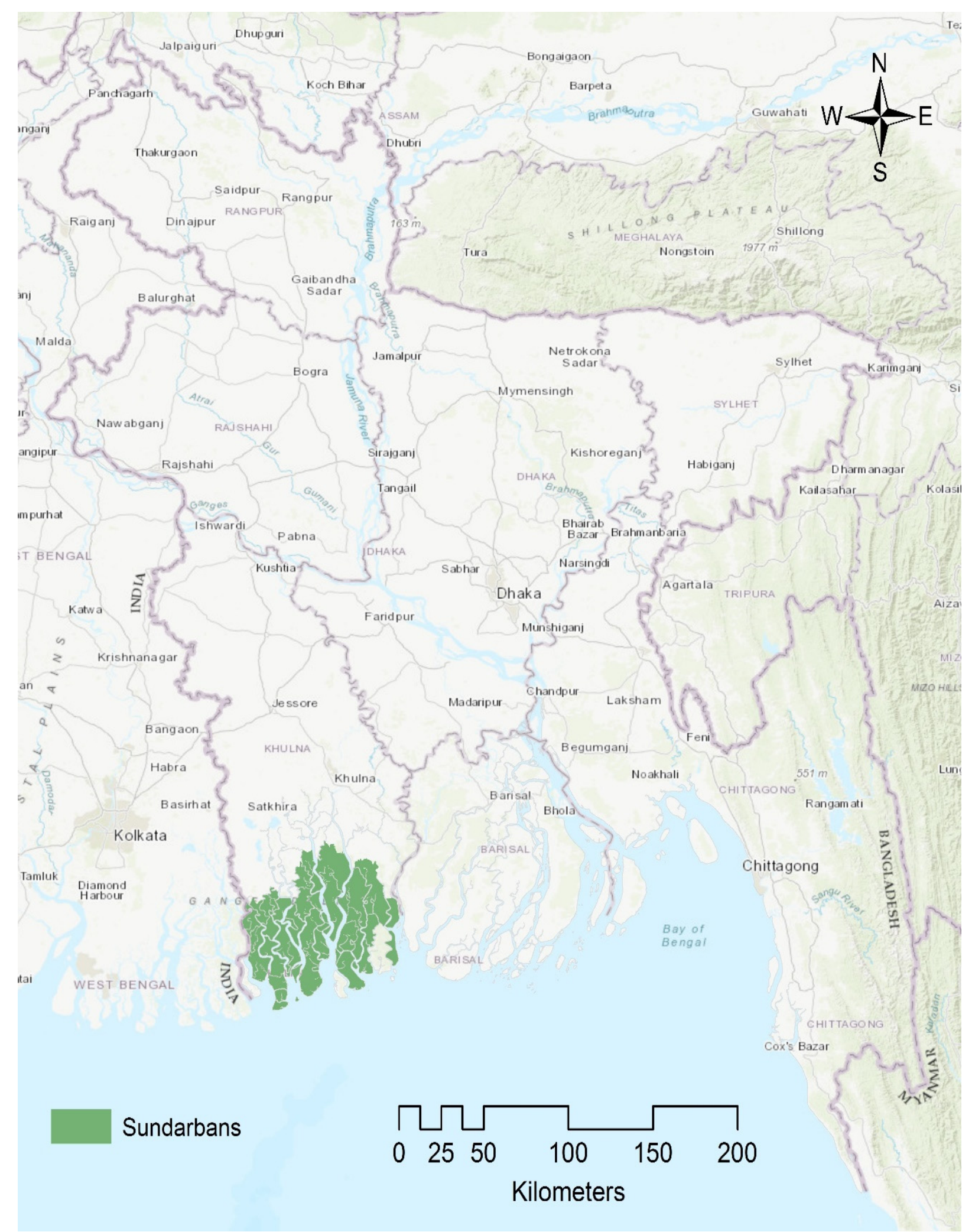

Figure 1. Location of the Sundarbans in Bangladesh

According to the World Resources Institute (WRI), the world lost a total of 474000 ha of mangrove land from 2001 to 2012 (1.38\% since 2000) (WRI, 2015). Gilman et al. (2008) stated that due to anthropogenic and natural causes about $35 \%$ of the world's mangrove forest area has been lost in the past two decades with an annual loss 
rate of $1-2 \%$. In the developing countries of Asia, the losses of mangrove forest are in the range of $50-80 \%$ due to conversion of forest to shrimp farming (Roy et al., 2013). Agricultural expansion and the use of fertilizers and pesticides is deemed to be the major cause of the mangrove reduction in Asia (Sarker et al., 2019). Population pressure and urbanization are also responsible for clearing considerable mangrove lands (WRI, 2015). Despite numerous benefits, the destruction of the Sundarbans in Bangladesh continues at an alarming rate (United Nations Educational, Science and Cultural Organization [UNESCO], 2017; Sabbir, 2012). Two factors, over exploitation of natural resources and adverse climatic conditions, are reported to be significant in the degradation of the Sundarbans (Roy, 2016; Hussain, 2014). Before the cyclone Aila in 2009, 29\% of the SIZ economy was based on agriculture and small-scale businesses, supported by well-developed infrastructure. Currently, approximately $80 \%$ of the people in the SIZ are directly dependent on the Sundarbans due to damages of infrastructure as well as loss of income generation opportunities because of recent natural disasters (Swapan and Gavin, 2011). These adverse effects threaten the sustainability of the Sundarban Reserve Forest (SRF) and the livelihood security of forest dependent people (Badola et al., 2012).

Given the vulnerability of the Sundarbans, the conservation of biodiversity and sustainability of the mangrove reserve forests is considered high priority in Bangladesh. The current paradigm of conservation planning continues to focus on establishment of protected areas and recognition of important habitat (Hansen et al., 2010). As well, resilience thinking has become an important concept in managing the complex and diverse relationship of humans and nature (Mazumder et al., 2018). To increase resilience of systems, Hansen et al. (2010) introduced the "climatesmart" conservation principle along four basic tenets: "protect adequate and appropriate space, reduce non-climate stresses, apply adaptive management to implement and test adaptation strategies immediately, and reduce the rate and extent of climate change to reduce overall risk to the conservation unit of concern" (Hansen et al., 2010, p. $63)$.

This study explores attitudes of stakeholders in forest-dependent communities within the Sundarbans mangroves with a view to advancing sustainable management and conservation of the Sundarbans. Our work also provides recommendations to improve sustainability of mangrove forests.

\section{Methods}

\subsection{Proposed Conceptual Framework for Mangrove Conservation}

Taking into account conservation models (Sustainable livelihoods framework [ DFID, 1999], linkages between livelihoods and biodiversity conservation [BCN 1997 and Salafsky, 1998], a general model of conservation [Salafsky and Margoluis, 1999], Community-Based Mangrove Forest Management (CBMFM) [ELAN, 2011] ), and a people-oriented approach, this work presents five key factors as a means to strengthen conservation of mangrove forests: a. International initiatives, b. State government policies and NGO's, c. Local communities, d. Benefits, and e. Threats and vulnerabilities (Figure 2). The framework attempts to identify linkages and feedbacks among these factors that influence decision-making in support of mangrove conservation. It will be argued that guidelines required to effectively manage mangroves must take into account the interactions and dependencies implicit in the proposed framework.

\section{a. International Initiatives}

For the betterment of humankind, world leaders periodically participate in international initiatives as a means of achieving a common (global) vision to address conservation issues, including the loss of biodiversity. Through discourse and consensus building, delegates seek solutions to address the degradation of natural systems. Over the last decades, several conferences linked directly and indirectly to conservation provide a basis for assessment, response, and strategic approaches to conservation, including the formulation of future policy regimes. These include: Ramsar Convention (1971), Rio Conference (1992), Kyoto Protocol (1997), New Delhi declaration (2002), Copenhagen Climate Conference (2009), United Nations Climate Change Conference at Durban (2011), Doha Amendment (2012), the 3rd International workshop for conservation genetics of mangrove (2016), and the International conference on sustainable mangrove ecosystem (2017) (Korhola, 2014; ITTO, 2017). Considering the importance of mangrove forest, in 2016 UNESCO declared 26th July of each year as the "International day for the conservation of mangrove ecosystem" (UNESCO, 2016). In 2017, world leaders joined an international conference on sustainable mangrove ecosystem in Bali, Indonesia. The objective of the conference was to "identify ways in which mangrove restoration and sustainable management could contribute to the achievement of Sustainable Development Goals 13, 14 and 15 and the Paris Agreement on climate change" (ITTO, 2017, p.3). The representatives of different countries shared their views on sustainable mangrove management while they focused on livelihood of resource dependent communities, adaptation and mitigation of climate change, strengthening good governance, laws and policies, payment method for environmental services and increasing 
research and awareness (ITTO, 2017; Islam, 2014).

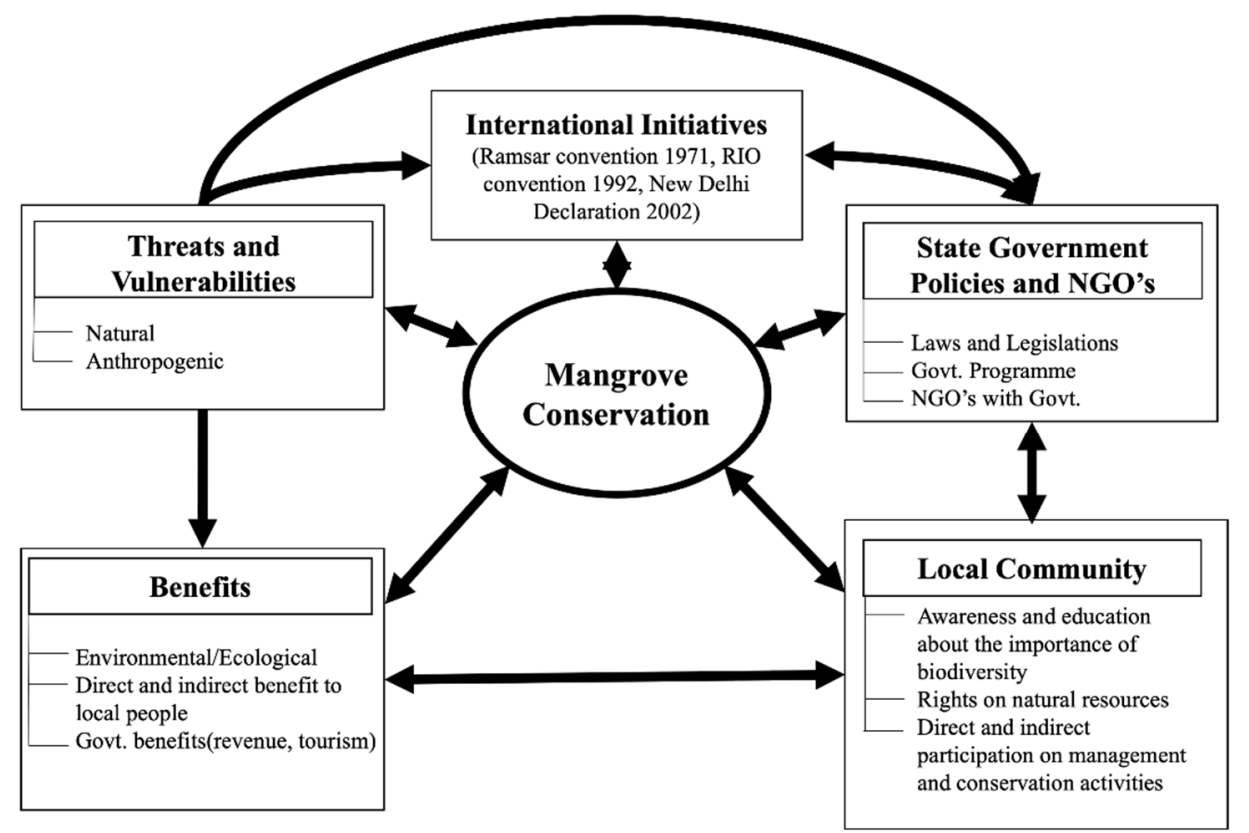

Figure 2. Proposed conceptual framework for mangrove conservation

\section{b. State Government Policies and NGO's}

Regarding the outcomes of international initiatives, state governments are encouraged to incorporate recommendations into their existing national and regional policies and to set appropriate goals to promote conservation. For example, the 2017 international conference on sustainable mangrove ecosystems at Bali, Indonesia provided recommendations to sustain mangrove forests. Its key message was 'prioritizing the conservation and sustainable management and use of mangrove ecosystems in national policies, laws and regulations at all levels of government, and strengthen law enforcement to reduce the continuing loss and degradation of mangrove ecosystem'(ITTO, 2017, p.53). The conference also focuses on land-use planning, effective mangrove restoration, financing mechanisms and generating and disseminating of knowledge. In Bangladesh the guidelines for mangrove forest management lie under the national forest policy which is largely designed to alleviate poverty by involving NGO's and local stakeholders by enhancing biodiversity management activities (GOB, 2016b).

\section{c. Local community}

Toit (2002) argued that success or failure of natural resource conservation highly depends on local people. Conservationists are particularly concerned with the rights of local people to the commons and therefore often focus their research on strategies to involve the resource users (stakeholders) into environmental services (e.g., guard of the common resources, replanting etc.) (Roy, 2016). Providing economic support to community people for conservation activities is one of the means to improve mangrove management (ITTO, 2017). Moreover, education and awareness of citizens about sustainable mangrove management, helps defined property rights and responsibilities of stakeholders on commons.

\section{d. Benefits}

Both government and local people benefit from conservation activities. In many developing countries a sustainable forest could be the most promising economic resource for forest dependent people. State governments, like those in Bangladesh, are also aware they get more revenue from a well-managed forest. In both economic and ecological terms, the benefits of a mangrove forest are many: timber, fuel, value-added products, carbon sequestration, water filtration and protection of coastal communities from natural hazards. Indeed, mangrove forests are noteworthy for biodiversity richness and productivity given their abundant and unique flora and fauna that span both terrestrial and aquatic environments (Mazumder et al., 2018; UNESCO, 2016; Alam, 2009). On the other hand, the local 
community would increase their benefit by preserving the forest resources: maintaining proper rules and regulations, prohibiting overexploitation and illegal harvesting, helping in management programme, and increasing awareness about conservation activities.

\section{e. Threats and Vulnerabilities}

Mangroves are facing two major types of threats: natural and anthropogenic. Naturally, the plants of mangrove forests are sometimes affected by diseases or destroyed by natural hazards. For example, during the last 30 years the Sundari trees of Sundarbans continue to decline due to top-dying diseases and salinity (The Daily Star, 2018; Mondal, 2017). The forest was also impacted by cyclones Sidr in 2007 and Aila in 2009. Globally, mangrove forests are facing anthropogenic threats because of overexploitation, establishment of infrastructures around the buffer zone, fisheries or other economic activities. Deforestation due to agricultural activities remains a major anthropogenic cause for mangrove degradation (Ghosh et al., 2015). These kinds of threats and vulnerabilities have serious negative impacts and reduce benefits to local communities (Valiela et at., 2001). By assessing threats and vulnerabilities state governments could incorporate guidelines into their forest policies while international organizations could better assist in developing and implementing state policy.

Potential Threat to the Sundarbans of Bangladesh: Bangladesh is planning to implement a $1320 \mathrm{MW}$ coal-based power station only $14 \mathrm{~km}$ away from the border of the Sundarbans (Banktrack, 2019) and within the SIZ. Typically, a 500MW power plant produces 125000 tons of ash and 193000 tons of sludge each year which contains elements of toxic chemicals (Chowdhury, 2017). Moreover, the process of producing electricity in a coal-based power plant is deleterious to the surrounding biodiversity. The power plant produces electricity by burning coal to produce water-steam which under tremendous pressure turns turbine(s) to generate electricity. To bring the coal to the power plant a river channel will be used which poses a hazard to aquatic life and creates traffic in the riverways. Moreover, untreated air (there is no air treatment plant in the design) produced by the power plant will contain nitrogen and sulphur gases $\left(\mathrm{NO}_{2}\right.$ and $\left.\mathrm{SO}_{2}\right)$ which contribute to acid rain. Failure of proper disposal of waste products from the power plant could potentially pose threats to water, air and soil and be a risk to residents. Finally, noise produced by the power plant might add a further disturbance or risk to biodiversity (Chowdhury, 2017; SAHR, 2015). UNESCO has described the situation as a 'potential threat' for the Sundarbans (UNESCO, 2017).

Herein, the proposed framework for conservation of mangrove forests represents a unified model of conservation by linking those points discussed above ( $a, b, c, d$ and e). It can be argued that as world leaders continue their efforts to solve global problems and produce guidelines and targets for consideration by state governments, it is critical that all countries, including Bangladesh, take into account principles of sustainability, with particular emphasis on SESs and the concepts of resilience, adaptability and transformability. Taking into account issues of sovereignty and national priority, Bangladesh must also agree to binding and nonbinding international agreements, and at multiple levels (national, regional, district) to try to fulfill their commitments by involving local stakeholders in decision-making and local conservation management activities.

\subsection{Selection of Study Areas}

The Sundarbans is located at the south-western geographical corner of Bangladesh, which is in the southern part of Satkhira, Khulna and Bagerhat districts (FD, 2015) (Figure 3).

This study focuses on the districts of Khulna and Satkhira, both of which are located within the Khulna Division. Among 14 subdistricts of the Khulna district, Dacope sub-district was selected based on proximity to the SIZ and on accessibility to the researcher. There are nine unions in the Dacope subdistrict, however only five were within the SIZ, and therefore met the selection criteria for the study. Each village was assigned a unique number and placed in a jar. Following mixing, two numbers (unions), Laudove and Pankhali, were randomly selected without replacement. Among the seven villages located in Laudove union, two villages, Harintana and Khutakhali, were selected using the method described above. Similarly, in Pankhali union with its 18 villages, two villages, Katabunia and Moukhali were selected. In the Satkhira District, Harinagar and Dhankhali villages of Munshigong union were selected. Population size for the seleted villages is shown in Table 1. 
Table1. Population demographics in villages selected for the study survey

\begin{tabular}{lc}
\hline Villages & Population Size \\
\hline Harintana & 541 \\
Khutakhali & 2142 \\
Katabunia & 1500 \\
Moukhali & 2550 \\
Harinagar & 249 \\
Dhankhali & 234 \\
\hline
\end{tabular}

Source: Bangladesh National Portal

\subsection{Data Collection and Analysis}

The proposed theoretical framework described above was used to guide the collection and analysis of qualitative data and to assist in exploring the relationships among those elements within the proposed model. A survey questionnaire was prepared to collect data from the six villages noted above. The questionnaire was designed to meet the objectives of the research initiative. Besides demographic information, the survey examined the attitudes of villagers on the issues of management, access to the resource, conservation, education levels, property size and rights and on their relationship with the Sundarbans. These data were then used to identify pressing policy issues and to assess how policy might be improved. Three collaborators from Bangladesh helped this researcher gather data. These individuals were working with different NGO's located near the Sundarbans and had valuable experience in survey work. The data collection process began with a discussion of the questionnaire with the collaborators. To be consistent in our survey, collection of data started from the center of the villages and continued along the main roadside of the village until the desired number of respondents were interviewed. Surveys continued until data from 60 respondents were prepared from the villages, a number determined by resource availability and time constraints. Data were collected from the head of the household because they are likely the resource collectors (Roy, 2014). Data were collected from mid-July to August.

After collecting data, all hardcopies were compiled and entered into an excel spreadsheet. The data were analyzed using Microsoft Excel software. Descriptive statistics were compiled in tabular and graphic forms to examine data trends. Qualitative data were analyzed by selecting key words of the respondent's answers to generate categories (Creswell, 2013). 


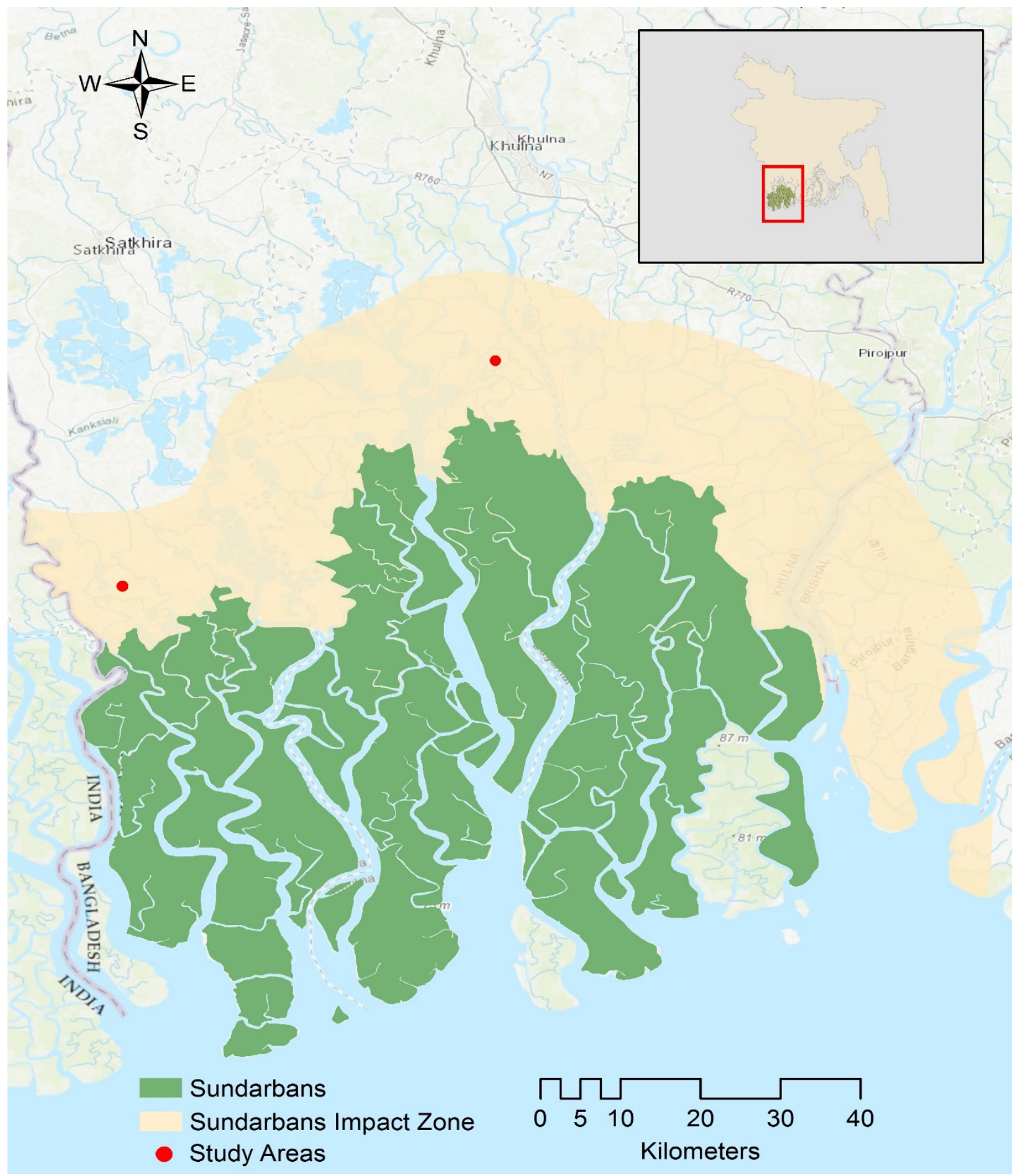

Figure 3. Map of the Sundarbans area (Bangladesh part), SIZ and study areas

\section{Results}

\subsection{Demographic Information of the Respondents}

Demographic information collected from respondents reflects the socio-economic condition of individuals and their family unit. By design, in this study, survey responses were limited to individuals who serve as the head of the households, as it was assumed that the members who usually serve as decision-makers within the family unit putatively contribute more to sustainable forest management practices. Because the head of the family (usually men) has decision making power in the family, they also exert a degree of influence on community decision- 
making. In our study, $63.33 \%$ respondents were middle aged (30-50) and $48.33 \%$ had primary education (Table 2).

Table 2. Educational qualification of the respondents

\begin{tabular}{lll}
\hline Category (grade) & Number $(\mathrm{n}=60)$ & Percentage $(\%)$ \\
\hline Illiterate & 12 & 20 \\
Primary (1-5) & 29 & 48.33 \\
Secondary (6-10) & 11 & 18.33 \\
College (11-12) & 6 & 10 \\
University degree $(>12)$ & 2 & 3.34 \\
\hline
\end{tabular}

\subsection{Attitudes of the Respondents to the Resources of the Sundarbans}

\subsubsection{Relationship of Respondents with the Sundarbans}

To conserve the Sundarbans, it is necessary to assess, and where possible, improve the attitudes of stakeholders towards natural resources. Stakeholders who are closely associated with the forests are in the best position to understand the full value of the resource and to contribute to formulation of policies designed to effectively manage the forest. Among the 60 respondents, most (93.33\%) were community members as the respondents were within the SIZ. The respondents were within the range of $0.25 \mathrm{~km}$ to $5 \mathrm{~km}$ from the border of the forest. Most of the community members are dependent on the Sundarbans for their livelihood. Findings (Figure 4) disclosed that $1.67 \%, 10 \%$ and $51.67 \%$ of the respondents are involved with hunting, honey and beeswax collection, and firewood collection, respectively. This study also found that $80 \%$ of the respondents collect fishes and crabs from the rivers of the Sundarbans.

Most of the respondents collect forest products either occasionally or professionally. In this study, the collected products are categorized in four groups: firewood; honey and beeswax; fishes, crustaceans and mollusks; golpata. A significant number (81.67\%) of local people collect fishes, crustaceans and mollusks from the water resources (figure 5) of the Sundarbans, which is similar (85\%) to findings reported by Roy et al., (2013). Getzner and Islam (2013) also noted that most of the households (67\%) in the Sundarbans collect fish resources followed by crab harvesting (14\%) which supports the findings of this survey. However, this study also revealed that $33.33 \%$ of the respondents also collected golpata (Nypa fruticans) from the forest. 


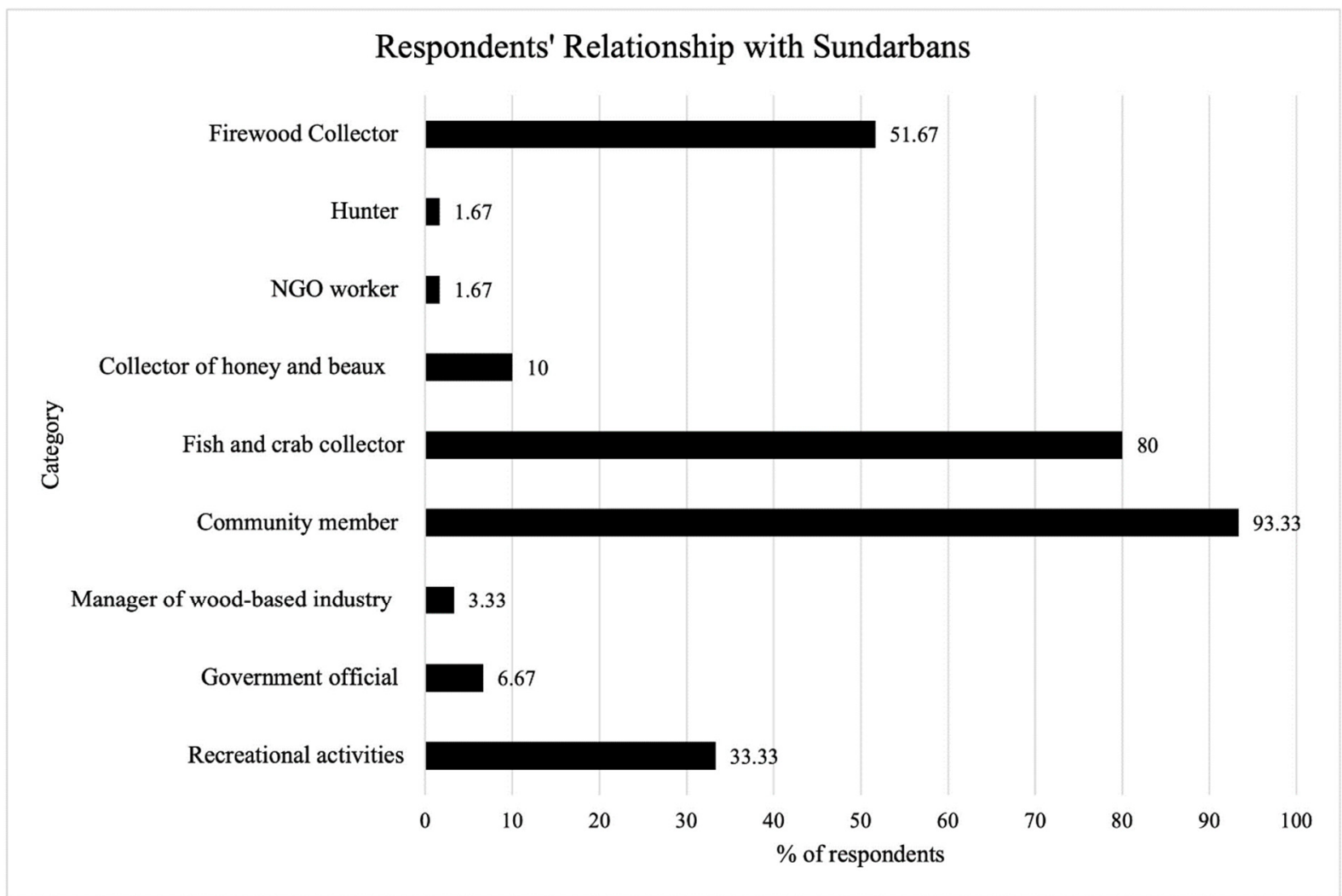

Figure 4. Relationship of respondents with the Sundarbans based on selected categories

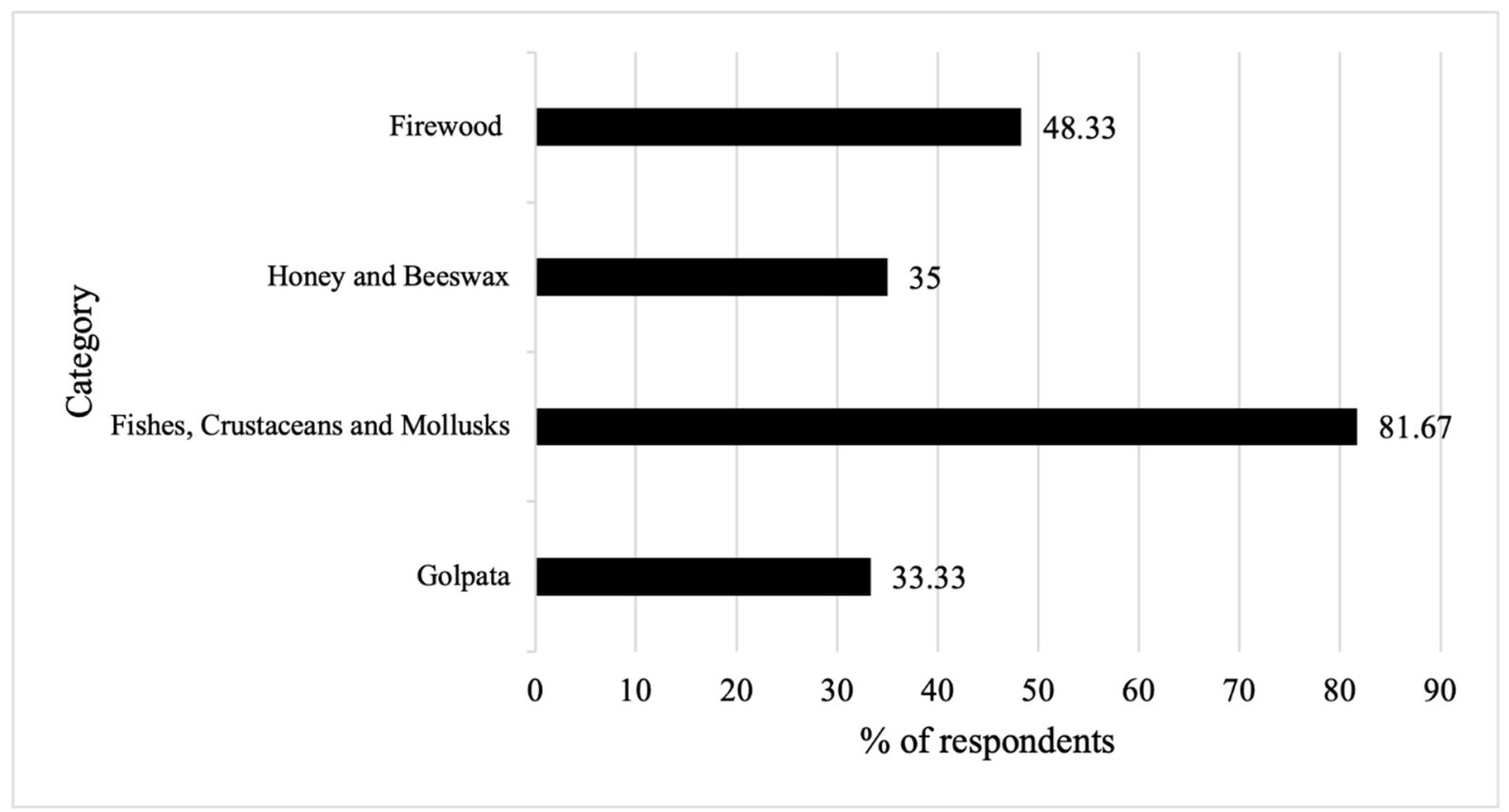

Figure 5. Types of collected natural resources from the Sundarbans

\subsubsection{Ranking of the Sundarbans as a Resource}

Despite current practices and the neglect of conservation efforts, no one ranked the mangrove forest as low in value which implies that the local people place high value on the mangrove forest as an asset (figure 6). According to a respondent, "It is a resource from where I can collect fishes, crab, golpata, firewood, honey etc. and by selling 
them I can earn money for livelihood".

Ideally, local people should be a part of planning and managerial activities. Local voices that can resonate with the BFD, and the Department of Environment would help set priorities and assist in the full implementation of an effective integrated management system. Unfortunately, most of the respondents $(80 \%)$ in this study said they have no voice on the management policy of the Sundarbans (figure 7). Most contend that more local input into planning and decision-making is needed and that attention to traditional knowledge should be incorporated into current policy. Furthermore, more effort should be made to implement policy.

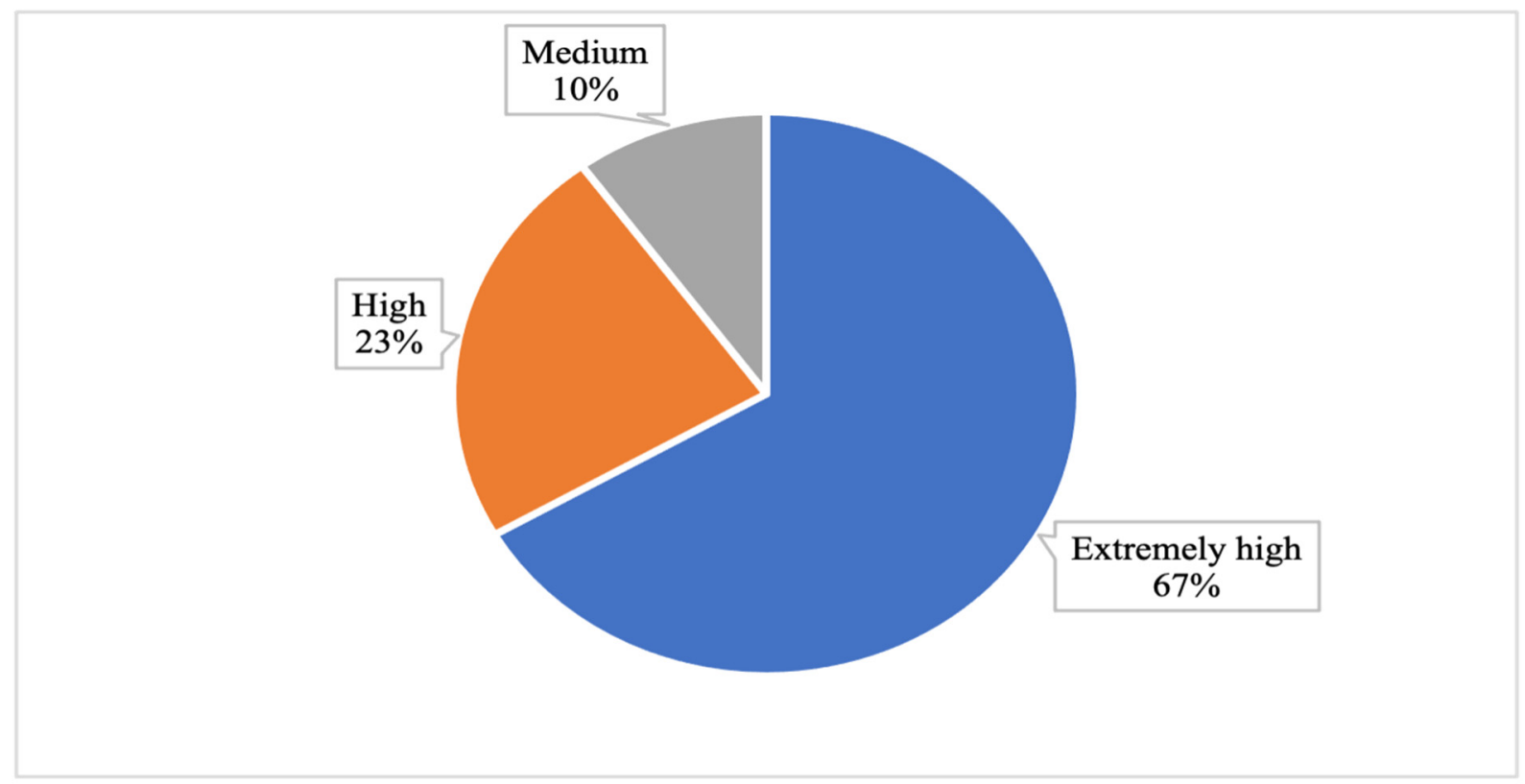

Figure 6. Ranking of Sundarbans as a resource

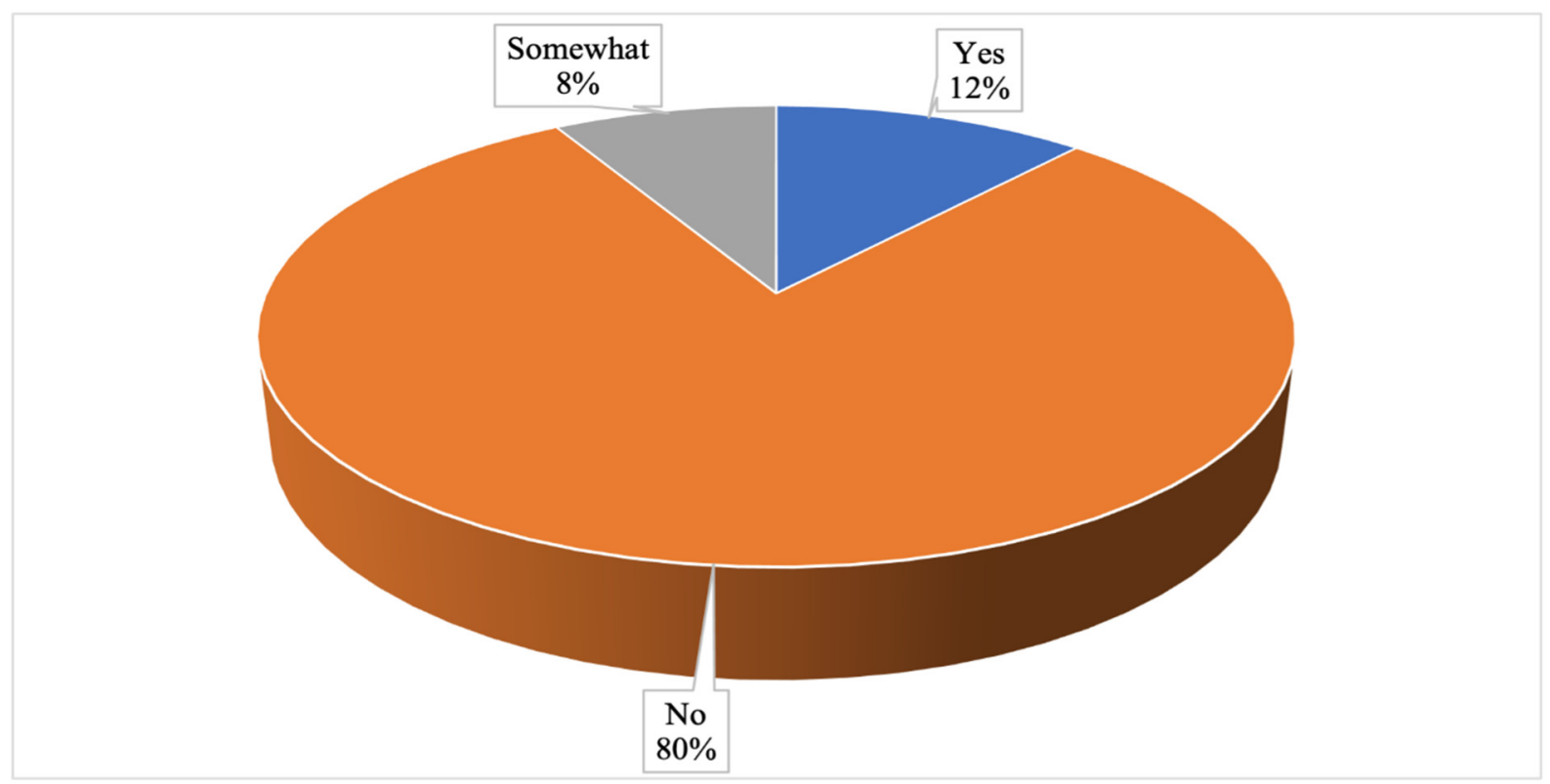

Figure 7. Attitude of respondents in the extent to which they have a voice on management policy of the Sundarbans

\subsubsection{Access and Frequency of Entry into the Mangrove Forests}

In Bangladesh, Sundarbans mangrove forest and water bodies are controlled by the state government. Traditionally, the right of access to Sundarbans is through membership in village communities dominated by the local elites. 
These rights are not formally regulated but are considered the birthright of the community. Results from this study confirm the high dependence of locals on the mangrove forests. Indeed, most people surrounding the Sundarbans require access to the forest for their livelihood. Findings (Figure 8) indicate that $47 \%$ of the respondents think they have adequate accessibility to the Sundarbans. For those respondents who gain access to the Sundarbans, $70 \%$ of them enter into the forest weekly while $23.33 \%$ of the respondents enter into the forest biweekly (Figure 9).

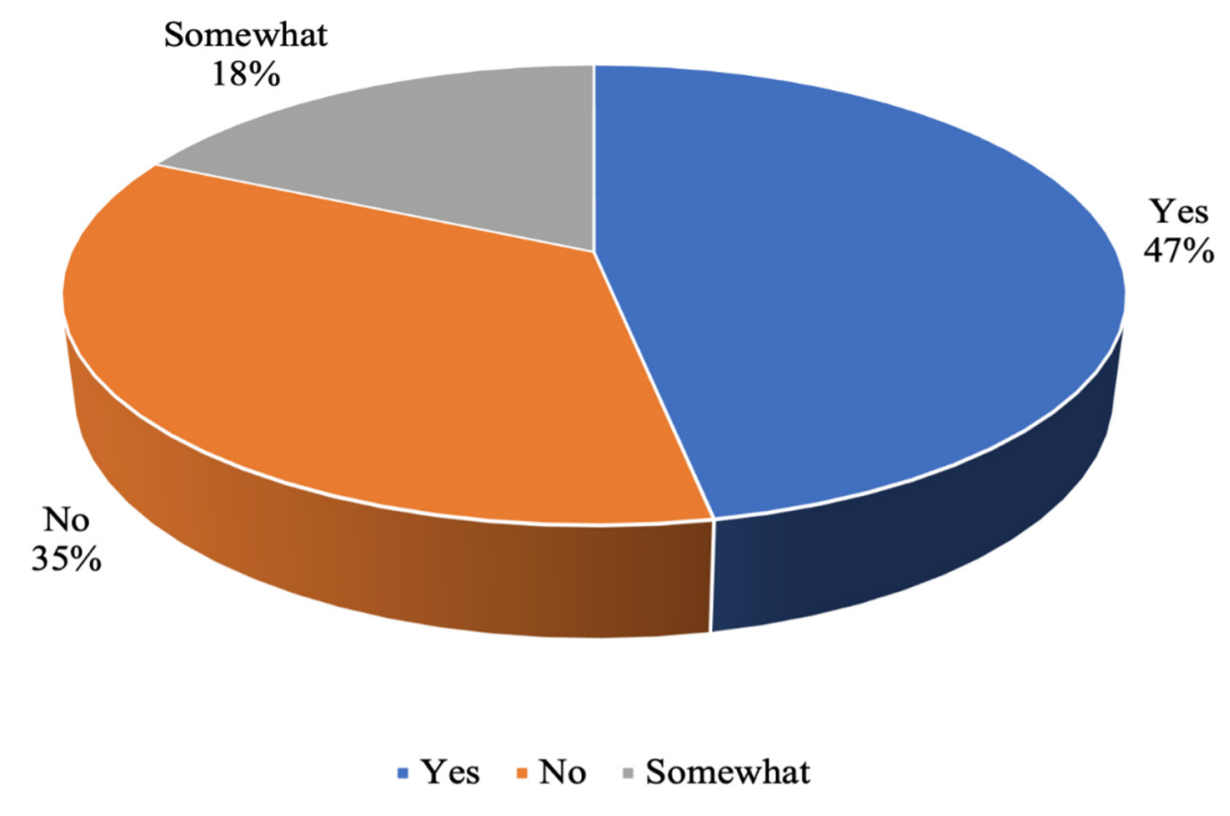

Figure 8. Access to the Sundarbans

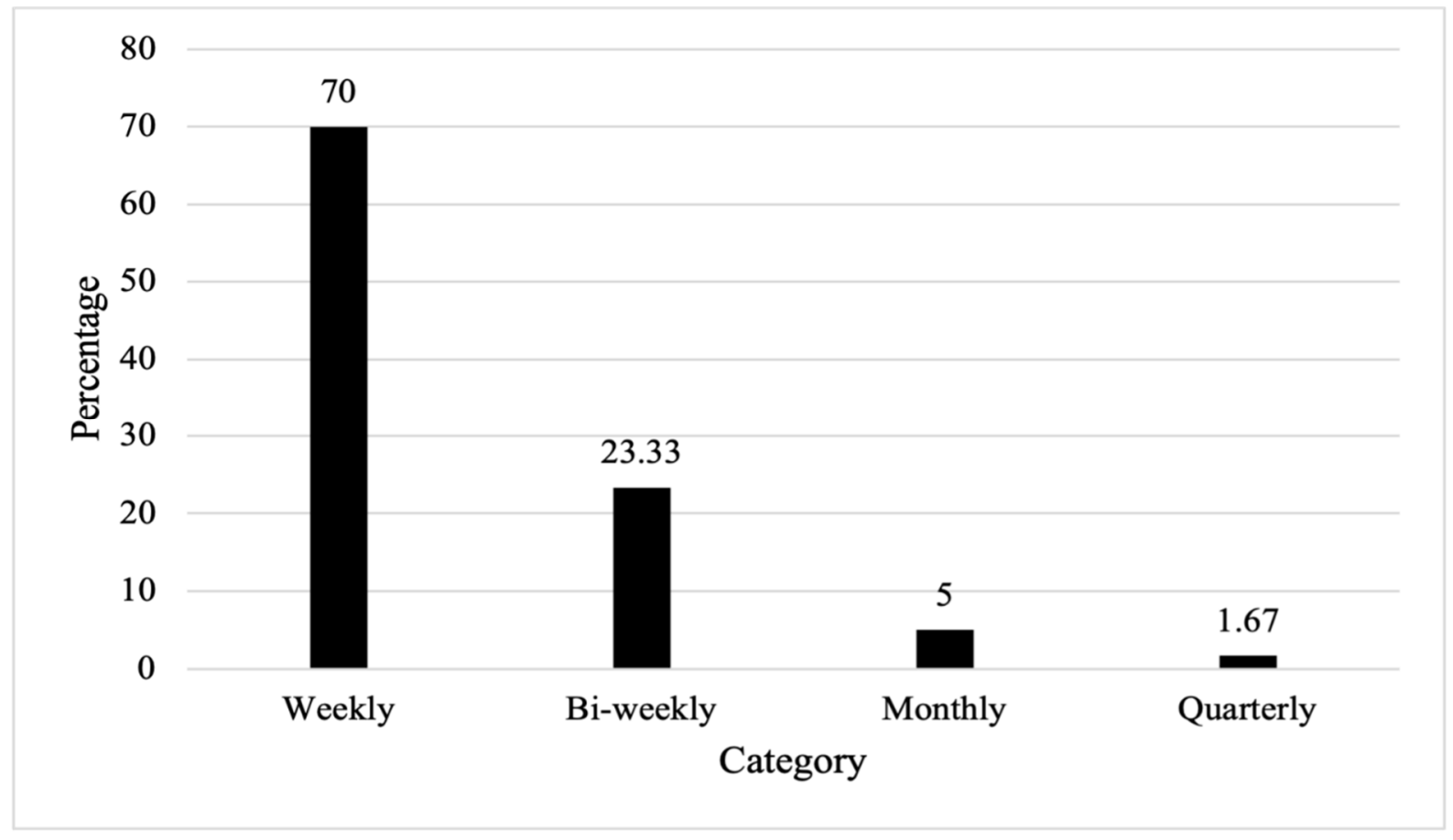

Figure 9. Frequency of respondents entering the mangroves 


\subsection{Attitudes on the Status of the Sundarbans}

Attitudes of the respondents towards natural resources reflect their way of thinking about the value of natural resources. In this study, respondents were surveyed to view their opinion on the status of the Sundarbans based on selected criteria: Sustainable to unsustainable, healthy to unhealthy, protected to unprotected, productive to unproductive, managed badly to managed well and attractive to unattractive. These criteria were chosen to reflect measures of satisfaction with sustainability issues and to gauge attitudes towards current management practices. Figure 10 shows the attitudes (based on average scores) of the respondents on the respective criteria. A preponderance of interviewees think that the forest is sustainable and productive. This may be because many generations have been able to subsist on the mangrove resources. Also, the resilience of the mangroves is noticeable to many locals. For example, after the devastating cyclones Sidr in 2007 and Aila in 2009, the Sundarbans appeared to recover with new biota reestablishing. After these cyclones, new trees have been replaced (growing) and to some extent look attractive. Although villagers feel the mangroves are naturally resilient and generally sustainable, they expressed concerns with current management practices. For example, half of the respondents said the mangrove forest is not protected and most of the people think the forest is badly managed. However, the link between management, protection and sustainability appears tenuous because $20 \%$ of respondents admitted they knew little about current government policies (figure 13). However, it can be argued from the survey results that people of the SIZ highly value the mangrove forest as a resource and they are highly dependent on the mangrove resources for their livelihood. Realizing the value of the resource to local communities, government has established three wildlife sanctuaries in the Sundarbans designated as protected areas. Entering in the forest to exploit resources without the permission of FD is completely illegal. Moreover, in this study, a number of respondents raised concerns of increasing salinity causing a degradation of their property. Similar concerns of increasing salinity in the Sundarbans has also have been reported by Sarker et al., (2016).

\begin{tabular}{|l|r|r|r|r|r|r|r|r|r|r|l|}
\hline Unsustainable & 1 & 2 & 3 & 4 & 5 & 6 & 7 & 8 & 9 & 10 & Sustainable \\
\hline Unhealthy & 1 & 2 & 3 & 4 & 5 & 6 & 7 & 8 & 9 & 10 & Healthy \\
\hline Unprotected & 1 & 2 & 3 & 4 & 5 & 6 & 7 & 8 & 9 & 10 & Protected \\
\hline Unproductive & 1 & 2 & 3 & 4 & 5 & 6 & 7 & 8 & 9 & 10 & Productive \\
\hline Managed Badly & 1 & 2 & 3 & 4 & 5 & 6 & 7 & 8 & 9 & 10 & Managed Well \\
\hline Unattractive & 1 & 2 & 3 & 4 & 5 & 6 & 7 & 8 & 9 & 10 & Attractive \\
\hline
\end{tabular}

Figure 10. Attitude of respondents ranked from 1 to 10 based on how they perceive the condition and management of the Sundarbans. The green marking showing the average scoring of the respondents on ranking scale 1 to 10

\subsection{Economic Value of the Sundarbans}

The Sundarbans offers direct employment opportunities to fishermen, boatmen, timber and NTPs collectors and tourist guides. Indirectly, it supports many downstream enterprises employing workers in the sawmill, fishery, and tourism industries who are dependent on the mangrove forest. Worldwide, there is a common tendency that underprivileged people are relatively more dependent on natural resources, given there are few alternatives for livelihood maintenance (Heubach et al., 2011; Assan and Kumar, 2009). This study directly addressed the attitudes of respondents towards the economic value of the Sundarbans. Not surprisingly, poorer and marginalized families are highly dependent for their income (Table 3) on the mangrove forest and view the mangrove resource as their only livelihood option. The majority of respondents viewed the Sundarbans as an important source of employment and indicated that government also derives significant revenue from the resource. Seventy percent of those interviewed realized the economic importance of the mangrove resource, and $62 \%$ recognized that natural products offer high economic potential. Such findings point to the critical need to conserve and sustain the natural mangrove ecosystem. These findings align with studies by Abdullah et al. (2016). More problematic is the knowledge reported by Islam and Hossain (2017) that forest harvesters have to pay 10 to 15 times higher fees to get a permit to enter into the forest than what is required under the standard government fee. These illegal approaches (higher fees) increase the expectations of users who may overexploit the resources. Interestingly, most of the stakeholders (67\%) disagree, some strongly, over the impact of agriculture and fish farming on Sundarbans (Figure 11). This response may be because the detrimental effects of agriculture and fish farming are less apparent or because the heavy dependence on such activities strongly influences opinions and there is a reluctance to take into account the 
known impacts of agriculture on sensitive mangrove ecosystems.

Table 3. Sources of income of the respondents

\begin{tabular}{lll}
\hline Category & Number (n=60) & Percentage (\%) \\
\hline Agricultural activities & 8 & 13.33 \\
Employment (Government/ Non-Government) & 5 & 8.33 \\
Day labor & 16 & 26.67 \\
Collect fish and crab from rivers of Sundarbans and sell in local market & 49 & 81.67 \\
Selling Non-Timber Product (honey, golpata, etc.) in local market & 7 & 11.67 \\
\hline
\end{tabular}

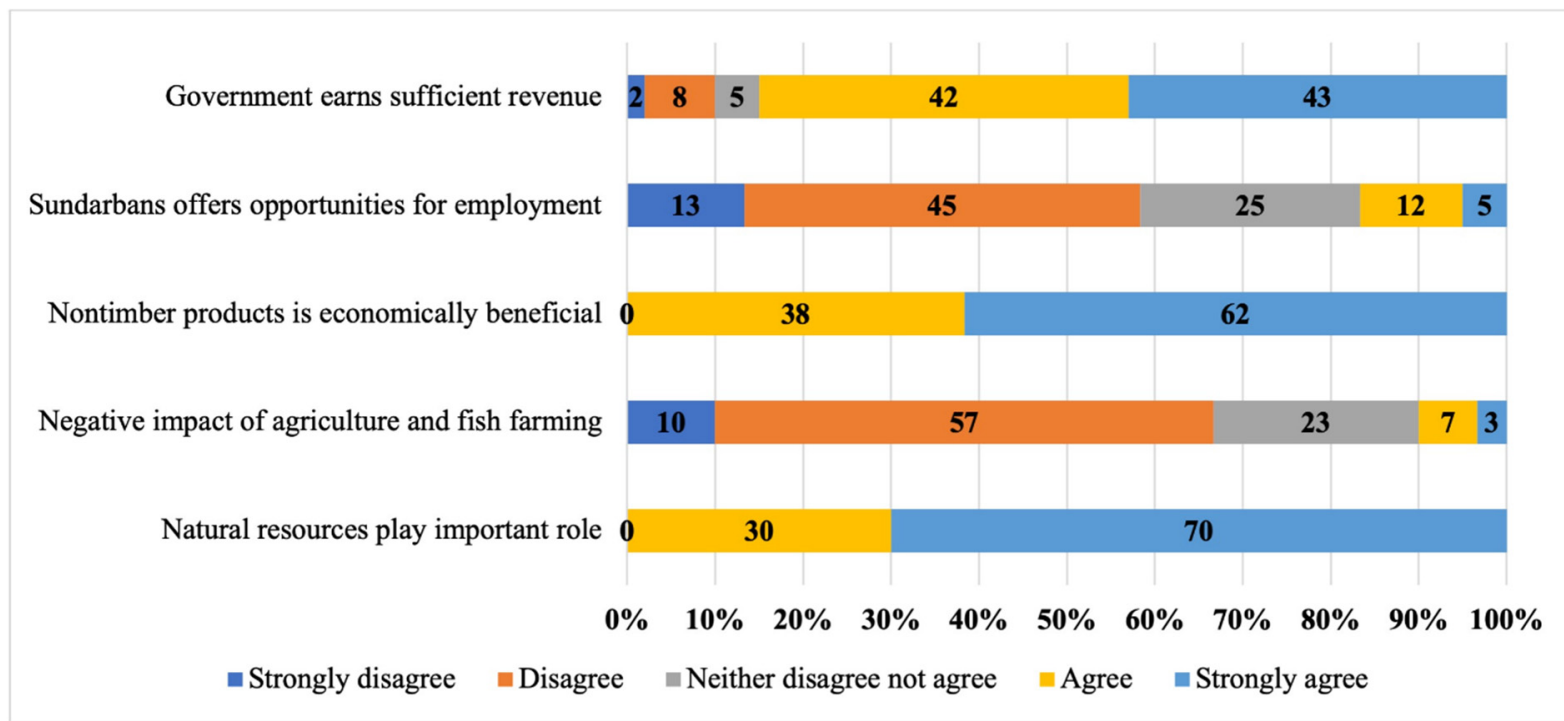

Figure 11. Economic value of Sundarbans by the respondents of SIZ

\subsection{Property rights of the Sundarbans}

Most of the forests in Bangladesh are under legal government ownership. The government manages forests through the FD and through the Ministry of Land. According to Ostrom (2000), "Property rights define actions that individuals can take in relation to other individuals regarding some 'thing'. If one individual has a right, someone else has a commensurate duty to observe that right (p. 339)". Privatization of property is typically 'transferring of activities' from government to the private sector with certain 'government regulations that limit individual rights' (Alessi, 1987). Roy et al. (2011) critically evaluated past forest management policies and property rights regimes in achieving sustainability of the SMF in Bangladesh. These authors argue that the existing state property rights regime is inadequate and fails to secure the livelihood of 3.5 million people in marginalized and disadvantaged forest-dependent communities in the Sundarbans. They further argue that to achieve sustainability in the Sundarbans there is a need to reverse the trend of rapid reduction of forest resources. The central issue to be considered is whether people need permission or a pass to extract natural resources from Sundarbans and how can they get that permission, or whether some form of management rights or ownership is justified. Currently, it is mandatory to get permission to collect any natural resources from the Sundarbans, so all the respondents (100\%) answered that they need to go through certain process for gaining permission or to obtain a pass to enter the Sundarbans. They first need to apply to the FD for a Boat License Certificate (BLC). The BLC depends on the size of the boat and to obtain this certificate they need a copy of their national identity card, two copies of passport size photos and a citizenship certificate from the local chairman (elected leader of the community). They can collect a variety of products, according to the BLC. The extraction of natural resources is also time bound. Fishes and crabs extraction are allowed year round while honey can be collected from April to June and Golpata (Nypa fruticans), can be collected from November to March (Getzner and Islam, 2013). Respondents see their current rights as being solely designed and controlled by insiders (e.g the BFD) and as being insufficient. Thus, some argue that their 
current rights are unable to meet the livelihood needs of their community.

Findings from this study indicate that a form of property rights (e.g., privatization) may be a means to promote sustainability of the resource. Respondents maintained that privatization of property would influence them to take care of the resources in a sustainable way and would be more effective than treating the mangrove as a common resource. A number of respondents did not think privatization of the property would result in a sustainable mangrove forest. One of them argued "the privatization of property would create more problems and the beneficiaries might misuse the valuable resources". A number of respondents commented on enforcement and its effectiveness. According to the survey, $78.33 \%$ of the respondents mentioned that FD inspects the extraction activity regularly (Figure 12).

\section{Responses related to property rights}

Users extract more resources than they have permit

Engage local people in forest management activities

Conflict between government people and resource collectors

Government people inspect the exploitation activities regularly

Privatization wanted

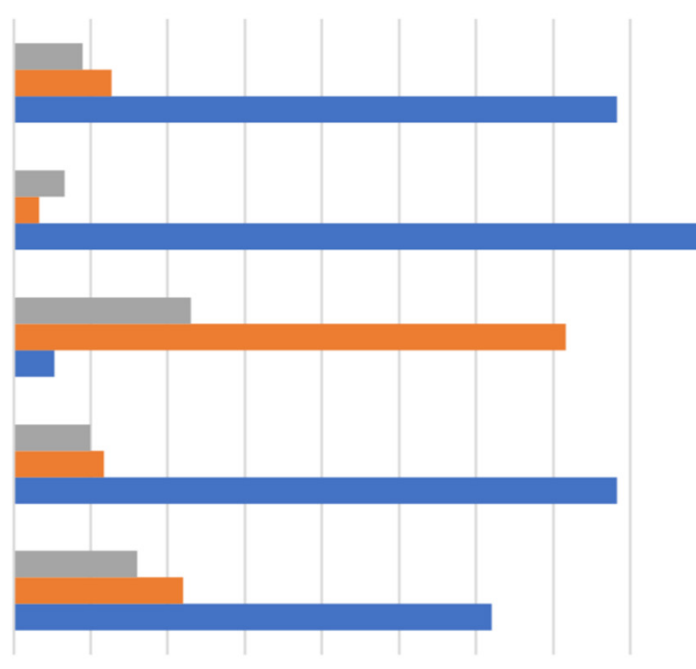

$\begin{array}{lllllllllll}0 & 10 & 20 & 30 & 40 & 50 & 60 & 70 & 80 & 90 & 100\end{array}$

No comments $\quad$ No $\quad$ Yes

Figure 12. Attitudes of respondents toward property rights of the Sundarbans

In some instances, community representation is involved in monitoring extraction activity through forest user groups. The members are selected from the local stakeholders and they can participate in the management process by Co-management Councils and Committee (CMC) programme of the government (Islam, 2014) which might decrease the conflict between FD and the local people. A few respondents raised concern about corruption and indicated that some stakeholders offer bribes called "bokhsis" to government officials during resource collection. Most of the respondents (70\%) claimed that water hijackers (pirates) are a threat to the forest. These hijackers frequent the rivers of the Sundarbans and sometimes hijack (seize) food and money from fishing boats. More extreme events may include kidnappings or killings. In some instances, fishermen have to pay the water hijackers on a regular basis. Ninety percent of the respondents believe that it is a good idea to engage local people and entrust them with more management rights. According to one respondent, "Sundarbans will be more protected if we can get more rights because the forest is the source of our income and everybody loves Sundarbans. But the FD should be careful about dishonest people". Generally, respondents argued for increased collaboration between the leaders of the community and the FD. This mechanism seems reasonable given that the villagers always present their demands through the leaders. Surprisingly, $78.33 \%$ of the respondents think that users extract more resources than they have permission to extract. Indeed, according to the respondents, some of the users do not have valid permits. Further commentary suggested that if more rights were granted to the resources of the mangrove forest, there would be more incentive to manage the resources sustainably and follow laws imposed by the government of Bangladesh.

\subsection{Forest Policy and Participatory Governance}

The concepts underlying participatory approaches to development and sustainability are underpinned by the roles 
of institutions and models of individual action. To promote a more integrated approach to the management of mangrove forests, a sustainable livelihood assessment (SLA) is often used to provide for meaningful participation by local people. As noted above, various frameworks exist to facilitate increased participation and promote more sustainable approaches to resource management. The proposed framework presented herein (Figure 2) calls for direct and indirect participation by local communities to allow for wider input and debate. While different frameworks will have different trajectories, Figure 2 makes clear the need for local community linkages taking into account the need for more awareness (education), and rights (property) of citizens. While Bangladesh, under the 2016 policy draft, has committed to more comprehensive and participatory approaches (e.g., the emergence of social forestry), it is clear from respondents that much is needed to effect full transformation of current forest policy. A significant number (57\%) of respondents indicated the current management practices may result in a sustainable mangrove forest (Figure 13). However, $23 \%$ of the respondents think that current management practices might not result in a sustainable forest. More problematic was the finding that $20 \%$ of the respondents are unaware of current forest management policy.

\section{Attitudes on current management policy}

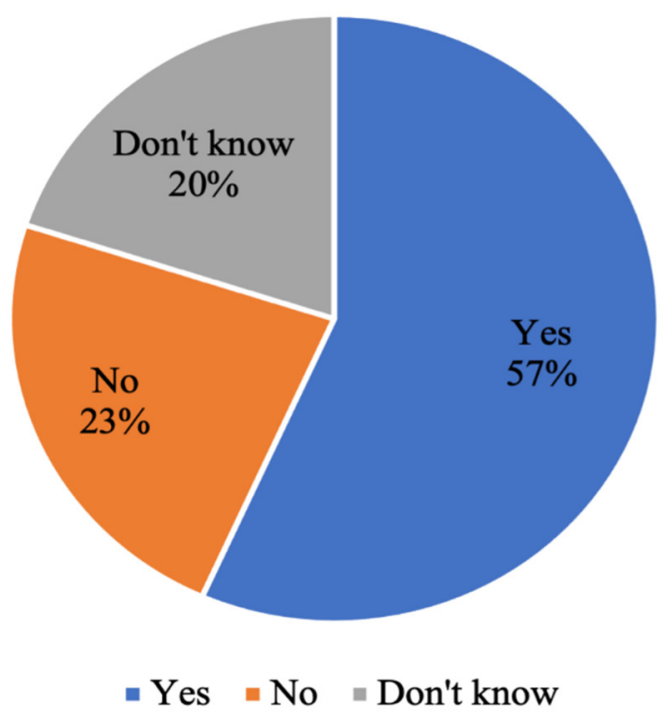

Figure 13. Attitudes of respondents toward current management policy as to whether the mangroves are sustainable

Findings from this research revealed that $88.33 \%$ of the respondents are involved with different government and nongovernment programmes including the VCF (village conservation forum), PF (peoples' forum), VTRT (village tiger response team) through meetings where they gather in a place with government officials or NGO's representatives and discuss issues related to the Sundarbans. During these meetings, local people have an opportunity to try and improve their condition under the current policy. Early studies by Roy (2014) found that $83 \%$ of respondents maintained that sustainable management practices are not being followed. In a related study on the Indian Sundarbans, Badola et. al., (2012) found that the people around the forest value it and are willing to participate in conservation activities. In the current study, respondents mentioned three major issues - safety from water pirates, the process of getting access (passes) should be easy and lower in price, and more training on the conservation of wildlife and timetable of collecting resources. Respondents demanded that regulators impose stricter rules and regulations designed to protect them from pirates during collection of resources and increase the number of forest camps and inspections. According to the respondents, increased collaboration and meetings among VCF, PF, and VTRT would strengthen management, given that insufficient and inefficient people are serious weaknesses of the current management policy.

The extent to which decision-makers respond to stakeholder needs including greater participation in management and policy processes requires a major paradigm shift involving a transition from a long-standing, top-down paradigm to a more diversified, bottom-up paradigm. In effect, this requires a transfer of power from the 'elite' which have dominated decision-making, to subordinates who utilize the resources on a regular basis and who have 
therefore, a vested interest in sustaining the resource. Thus, it can be argued that stakeholders in the SIZ, many of which are poor, need to be empowered to enable them to take command and act directly themselves. To a great extent, empowerment of the poor requires reversals and changes of role and therefore a 'rethinking' of past practices. It also implies substantive changes in bureaucratic processes and cultures, and in particular the extent of local participation process. In recent years, a degree of consensus has emerged around the desirability of participatory democracy and is the subject of governance and policy reforms (Baiocchi and Ganuza 2016). Participatory democracy is, according to Baiocchi and Ganuza (2016), an imperative of our time and no longer a counterpoint but a part of the planning of power itself. Roy and Gow (2018) argue that planning targets cannot be met unless local participation is ensured through a deliberative framework. It is also noteworthy that participatory approaches have become an established orthodoxy among development agencies across the political spectrum. Within this context, there is a strong call for involvement of women in participatory strategies. The latter is highly relevant to Bangladesh where, to date, gender inequalities exist. Men (as head of households) most often influence strategic resource development priorities and decision-making processes. One possible means to ensure wider participation, including a role for women, is to involve women in the identification of criteria and indicators to monitor progress towards sustainability and environmental management goals established for the Sundarbans. Such empowerment could build capacity, involve marginalized groups, increase dialogue, promote open decisionmaking spaces, and incentives to participate. Inevitably, wider participation would promote diplomatic resolutions to management and/or policy conflicts.

\section{Discussion}

The proposed framework acted as an analytical tool with several variations and contexts. Further, it was used to make conceptual distinctions and organize ideas. Strong conceptual frameworks capture something real and often do this in a way that is easy to remember and apply.

\subsection{Socio-economic Condition of the People of SIZ}

Numerous reports suggest that discrimination of rights based on gender, financial condition of the resource collectors, or offers of political support are familiar phenomena at play in getting access to common property. This study revealed that the people of SIZ are highly dependent on the Sundarbans for their livelihood. It is significant that some workers in the Sundarbans find it necessary to participate in multiple jobs. A day laborer might collect honey seasonally (April to June) from the forest and also occasionally participate in the collection of fish. The annual family income of the respondents ranged from US $\$ 700$ - $\$ 4550$ ( 1 USD $=84.48$ [Bangladesh Taka] BDT) and the average income for 60 respondents was US\$1138 which is below the national average income (US\$1466) (GOB, 2016) in Bangladesh. In a livelihood study on the Sundarbans, Abdullah et al. (2016) found the annual family income of US\$1122 which is similar to findings reported herein. In 2019, the Gross Domestic Product (GDP) per capita was US\$ 1827 in Bangladesh. The poverty line is estimated by the availability of food for the family. Among many developing countries there is evidence that poor and underprivileged people live adjacent to forest resources (Isbell et al., 2017; Langat et al., 2016). In a study in China, Hogarth et al. (2013) also found that the poor income groups were more reliant on forest income than relatively rich households, due to lack of alternative income sources. Despite the reliance of many poor people on the forest resource, Mondal (2017) reported a negative impact on conservation activities. This suggests a serious lack of concern for forest sustainability and calls for policies that protect and sustain valuable forest resources. This finding has particular relevance for the Sundarbans, because many forest dependent people live their life at or below the poverty line and can barely meet their minimum demands.

Regulation of accessibility of the local people to the common Sundarbans property is very difficult because local people contend that they have a traditional right to use the property. Moreover, within local communities, accessibility is controlled by political and elite leaders. Indeed, political power may assist special or higher interest groups to allow greater access to the resource. However, corruption is claimed to be a major constraint to successful implementation of many of the stated mangrove conservation practices in the SMF (Islam and Wahab, 2005). Understandably, malpractice or corruption represent a threat to the sustainability of the Sundarbans, given it can undermine fairness, and ultimately the participatory process itself, thereby compromising conservation efforts. Roy et al. (2013) bring attention to corruption within government and note that it was assumed that wider community participation in the planning and decision-making process would prevent corruption in the BFD. However, these workers further note that the BFD has maintained a conservation policy which excluded Forest Dependent Community (FDCs) from management and policy formulation.

\subsection{Sustainable Forest Management and Participatory Governance}

To respond to the challenge of mangrove sustainability, it is important to know the attitudes and concerns of 
respondents about the resources of the Sundarbans and how they benefit from the forest. Similarly, it is important to promote participatory approaches to decision-making if the livelihood of local communities is to be secured. Ultimately, sustainable management of the Sundarbans is dependent on stakeholder's attitudes towards the forest resource and their involvement in the decision-making process. Khan (2001) noted that in an effort to expand and conserve Bangladesh's natural forests, the government of Bangladesh has recognized the need for developing adequate policy and framework planning, including appropriate institutional reforms to promote user involvement in forest management and conservation. It can be argued that one prerequisite to successful management and to a sustainable future for residents of the SIZ is the need for them to recognize more fully the contribution of ecosystem services to their livelihood. Under the conceptual framework proposed in this thesis, there is a local community link that requires residents to have a significant appreciation of the benefits (value) of the Sundarbans. Moreover, stronger interactions with the government, NGOs and conservation efforts should elevate participation levels and ensure mangrove forest policies reflect the priorities and aspirations of local communities. Thus, the discussion below focuses on the relationship between residents and the Sundarbans. A measure of the attitudes and dependency of local communities on Sundarbans' natural resources is needed if mangrove forests are to stay high on the political agenda and if conservation strategies are to be developed in harmony with local livelihoods (Riddell, 2013).

Many residents within the SIZ collect golpata (Nypa fruticans) illegally during fishing (Islam et al., 2018; Roy, 2014; Getzner and Islam, 2014). Few of them might have other full-time work (agriculture, shrimp farm) or business, but are still directly involved with the Sundarbans through hunting, collecting firewood and recreational activities. Other residents also collect crab and shrimp fry from fishermen or are involved in boat building, which means indirect involvement with the forest. Mondal (2017) found that resource collection depends on the population size and poverty level. He reported that $57 \%$ of the people in the SIZ collect fuel wood from the mangrove forest. Mozumder et al. (2018) reported that people closer to the Sundarbans collect more firewood than people relatively away from the border of the forest. As expected, in most instances poor people are more dependent on the forest than those considered wealthy (Mondal, 2017).

It is clear from this study and from works cited above that there is a strong relationship between local communities and the Sundarbans with its concomitant resources. Local communities depend on the resources for food, housebuilding material, fuels, and recreation. To meet their needs, local communities harvested resources from forest either legally or illegally. Consequently, sometimes they overexploit the resources, occasionally neglect government rules and regulations, and at times mistreat the ecosystem. Not surprisingly, there is also strong competition among users for limited resources. These types of practices and attitudes offer a real threat to the ecosystem and complicate efforts to advance sustainable management of the Sundarbans. Therefore, it is essential that policymakers carefully consider stakeholders' attitudes towards sustainability in any decision-making approach.

In the proposed conceptual framework for mangrove conservation (Figure 2), the local community is the interactive component that bridges benefits and government policy. This assumes that deliberative democratic processes are desirable and possible. An effective participatory approach in community-based management is thought to represent peoples' empowerment (Mathur, 1997). As Benhabib (1996) argues:

According to the deliberative model of democracy, it is a necessary condition for attaining legitimacy and rationality with regard to collective decision-making processes in a polity, that the institutions in this polity are so arranged that what is considered in the common interest of all results from processes of collective deliberation conducted rationally and fairly among free and equal individuals (p.69).

While it can be argued that democratic legitimacy is not necessarily related to the success of conservation policies, most respondents agree that for conservation success, local participation is desirable. In the case of Bangladesh, the historical record indicates local participation is weak or ineffective. It should therefore be strengthened. Despite weak participation, data from this study indicate very significant relationships between respondents and the Sundarbans.

\section{Conclusions}

The Sundarbans mangrove forest, a UNESCO world heritage site, is the largest wetland forest in the world and is of great social, ecological and economic significance to the people of Bangladesh. The full value of the unique ecosystem cannot be monetized but with its array of forests and rich biodiversity, the mangrove ecosystem is a showpiece of natural history. It is also a center of economic activities where surrounding communities extract timber, fish, collect food (e.g., honey), to maintain their livelihoods. Despite their overwhelming importance, the Sundarbans, like many mangrove forests on earth, are under serious threat from natural hazards (e.g., sea level rise, 
cyclones) and from human activities such as human encroachment, illegal logging, tourism industries, unplanned development projects, forest clearing and related land use issues. Today, the area around the Sundarbans is densely populated and numerous people are engaged in the commercial exploitation of its resources. The challenge of conserving and managing the world's largest mangrove forest, is massive. During the past two decades, Bangladesh has improved its forest policy to help sustain the Sundarbans and to provide economic livelihoods to forestdependent communities. Regrettably, the recent decision to establish a coal-based electric plant in proximity of the Sundarbans denotes lack of consistent concern for the conservation of this UNESCO protected area. As a protected area, the Sundarbans is currently managed by the BFD under a state property rights regime. This study explores attitudes to sustainable forest policy and management of the Sundarbans. Given that the sustainability and management of resources are so complex, Ostrom (2009), Mozumder et al. (2018), and others, suggest that a social-ecological system (SES) framework should be considered to better understanding processes of use, maintenance, regeneration, and destruction of natural resources. The proposed framework (Figure 2) with its respective elements (community actors, governance, threats//vulnerabilities, and benefits) indicate interactions and links to conservation priority located at the center of the conceptual framework. It is provided in an attempt to reinforce 'SES thinking' and ultimately to influence decision-making. Most developing countries have well written forest policies, but frameworks are lacking or deficient, and the implementation of forest policy is often difficult due to competing policies, lack of infrastructure, inefficiencies, and insufficient funding. Bangladesh is no different, suggesting an ecosystem-based approach to forest management is needed to address future threats and vulnerabilities. In Bangladesh the challenges are heightened because mangrove forest management policy is "top down" (Roy, 2016) where the community has little voice in the management of the Sundarbans. This study found that the socio-economic level of the people surrounding Sundarbans is generally very low. Traditionally, local farmers harvest natural resources from the forest for their livelihood. Incorporating the villagers in the management activities with a form of co-management is one possible step to improving sustainable management of the Sundarbans. As such, the state could consider a shared benefit approach to ensure more stable economic conditions for the communities.

It should be noted that community-based management approaches that require strong participation by stakeholders has met with some resistance because it can be viewed by some as a form of political control. If progress is to be made, it must be recognized that a true participatory approach is one in which everyone's perspective is considered, as in participatory democracy. Equitable participation, trust, and respect among partners must serve as a foundation for improving the sustainability of the Sundarbans.

Based on data collected in this study, several specific recommendations follow:

- Government policy should strongly support and enhance educational opportunities for local people within the SIZ. More awareness of the full value of the Sundarbans would help to improve stakeholder attitudes towards sustainable management of the resource.

- Efforts should be made to advance coupled human-environment (socio-ecological) systems. These systems call for more participatory approaches to management that permit stronger voices from the local community. Wider participation would improve governance of the Sundarbans and address issues such as access, property rights, and illegal harvesting.

- Parallel efforts should be made towards local 'empowerment', to ensure common priorities and levels of agreement on both conservation and livelihood issues within well-defined and established form of participatory democracy.

- Introducing additional fuel sources such as biogas from cow dung or solar options as well as alternate income generation sources (e.g., handicrafts, goat farming, and fish cultivation) are recommended to reduce pressure on the mangrove.

- A number of policy instruments including financial incentives (subsidies or compensation), and regulations (access and allocations) should be considered to improve livelihoods that would in effect further reduce pressure on the mangrove resource. The government of Bangladesh should re-examine and foster the implementation of signed international conventions, treaties and protocols to protect the biodiversity of the Sundarbans, which in itself would promote sustainability.

- Information instruments, the political intervention that formally influences the social and economic action solely through "information", should also be better utilized. For example, communication strategies should be developed to better promote sustainability principles, ecosystem services, and to include local people in decision making. 


\section{Acknowledgments}

We would like to thank Mr. Ripon Kumar Ghose, Mr. Md. Abdul Hamid and Md. Mosaddek Hossain from Bangladesh for helping us in collecting data and Mr. Myron King from Memorial University of Newfoundland for creating maps for this paper. We also extend thanks to Memorial University's Environmental Policy Institute for graduate student funding to T. Mondal.

\section{References}

Abdullah, A. N., Stacey, N., Garnett, S. T., \& Myers, B. (2016). Economic dependence on mangrove forest resources for livelihoods in the Sundarbans, Bangladesh. Forest Policy and Economics, 64, 15-24. https://doi.org/10.1016/j.forpol.2015.12.009

Abdullah, N. M. A., Stacey, N., Garnett, T. S., \& Myers, B. (2016). Economic dependence on mangrove forest resources for livelihoods in the Sundarbans, Bangladesh. Forest Policy and Economics, 64, 15-24. https://doi.org/10.1016/j.forpol.2015.12.009

Aheto, D. W., Kankam, S., Okyere, I., Mensah, I., Osman, A., Jonah, F. E., \& Mensah, J. (2016). Communitybased mangrove forest management: Implications for local livelihoods and coastal resource conservation along the Volta estuary catchment area of Ghana. Ocean and Coastal Management, 127, 43-54. Retrieved from https://doi.org/10.1016/j.ocecoaman.2016.04.006

Alam, M. (2009). Evolution of forest policies in Bangladesh: A critical Analysis. International Journal of Social Forestry, 2(2), 149-166.

Alessi, L. D. (1987). Property rights and privatization. Proceedings of the Academy of Political Science, 36(3), 2435. https://doi.org/10.2307/1174094

Assan, J. K., \& Kumar, P. (2009). Introduction Livelihoods options for the poor in the changing environment. Journal of International Development, 21, 393- 402. Retrieved from https://doi.org/10.1002/jid.1565

Aziz, A., \& Paul, A. R. (2015). Bangladesh Sundarbans: present status of the environment and biota. Diversity, 7, 242-269. https://doi.org/10.3390/d7030242

Badola, R., Barthwal, S., and Hussain S. A. (2012). Attitudes of local communities towards conservation of mangrove forests: a case study from the east coast of India. Estuarine, Coastal, Shelf Science, 96, 188-196.

Baiocchi, G., \& Ganuza, E. (2016). Popular democracy: The paradox of participation. Retrieved from https://www.sup.org/books/title/?id=22421

Banktrack. (2019). Rampal coal power plant: Bangladesh. Retrieved from https://www.banktrack.org/project/rampal/pdf

BCN (Biodiversity Conservation Network). (1997). The Biodiversity Conservation Network: evaluating issues of business, the environment, and local communities. Retrieved from www.BCNet.org

Benhabib, S. (1996). Toward a Deliberative Model of Democratic Legitimacy. In S. Benhabib (Ed.), Democracy and Difference. Princeton: Princeton University Press.

Chowdhury, A. H. (2017). Environmental impact of coal based power plant of Rampal on the Sundarbans (world largest mangrove forest) and surrounding areas. MOJ Eco Environmental Sciences, 2(3), 85-98.

Creswell, J. W. (2013). Qualitative inquiry and research design: Choosing among Five Approaches (3rd ed.). Thousand Oaks, CA: SAGE.

DFID (Department for International Development). (1999). Sustainable livelihood guidance sheets. Retrieved from http://www.livelihoodscentre.org/documents/20720/100145/Sustainable+livelihoods+guidance+sheets/8f35 b59f-8207-43fc-8b99-df75d3000e86

Ecosystems Livelihoods Adaptation Network, ELAN. (2011). Community-based mangrove reforestation and management in Da Loc, Vietnam. Retrieved from https://www.preventionweb.net/files/25381_vietnam.pdf

Forest Department (FD). MoEF, Bangladesh. (2015). Wildlife Sanctuary. Retrieved from http:/www.bforest.gov.bd/site/page/f619019f-14cd-481a-86f4-1d5b4ae40515/Wildlife-Sanctuary

Getzner, M., \& Islam, M. S. (2013). Natural resources, livelihoods, and reserve management: A case study from Sundarbans mangrove forests, Bangladesh. International Journal of Sustainable Development and Planning, 8(1), 75-87. Retrieved from https://doi.org/10.2495/SDP-V8-N1-75-87 
Ghosh, S., Bakshi, M., Bhattacharyya, S., Nath, B., \& Chaudhuri, P. (2015). A review of threats and vulnerabilities to mangrove habitats with special emphasis on east coast of India. Earth Science and Climate Change, 6(4). https://doi.org/10.4172/2157-7617.1000270

Gilman, E. L., Ellison, J., Duke, N. C., \& Field, C. (2008). Threats to mangroves from climate change and adaptation options: a review. Aquatic Botany, 89, 237-250. https://doi.org/10.1016/j.aquabot.2007.12.009.

GOB (Government of Bangladesh). (2016a). Per capita income of Bangladesh rises to USD 1,466. Retrieved from $\mathrm{http} / / /$ data.gov.bd/story/capita-income-bangladesh-rises-usd-1466

GOB. (2016b). National forest policy 2016 (Draft). Retrieved from http://www.bforest.gov.bd/

Hansen, L., Hoffman, J., Drews, C., \& Mielbrecht, E. (2010). Designing Climate-Smart Conservation: Guidance and Case Studies. Conservation Biology, 24(1), 63-69.

Haque, Z. M., \& Reza, I. H. M. (2017). Salinity intrusion affecting the ecological integrity of Sundarbans Mangrove Forests, Bangladesh. International Journal of Conservation Science, 8(1), 131-144.

Heubach, K., Wittig, R., Nuppenau, E. A., \& Hahn, K. (2011). The economic importance of non-timber forest products (NTFPs) for livelihood maintenance of rural west African communities: A case study from northern Benin. Ecological Economics, 70, 1991-2001.

Hogarth, N. J., Belcher, B., Campbell, B., \& Stacey, N. (2013). The Role of forest-related income in household economies and rural livelihoods in the Border-region of Southern China. World Development, 43, 111-123.

Hussain, M. Z. (Ed.). (2014). Bangladesh Sundarban Delta Vision 2050: A first step in its formulation - document 2: A compilation of background information. IUCN, International Union for Conservation of Nature, Bangladesh Country Office, Dhaka, Bangladesh, pp. 1-192.

Hussain, Z., \& Acharya, G. (1994). Mangrove of the Sundarbans: Volume two: Bangladesh. IUCN, Bangkok, Thailand.

Isbell, F., Gonzalez, A., Loreau, M., Cowles, J., Díaz, S., Hector, A., ... Larigauderie, A. (2017). Linking the influence and dependence of people on biodiversity across scales. Nature, 546, 65-72.

Islam M. S., \& Wahab, M. A. (2005). A review on the present status and management of mangrove wetland habitat resources in Bangladesh with emphasis on mangrove fisheries and aquaculture. Hydrobiologia, 542(1), 165190.

Islam, M. M., \& Hossain, M. M. (2017). Community dependency on the goods and services from the Sundarbans mangrove wetland in Bangladesh (Forthcoming). Wetland Science: Perspectives from South Asia. Springer.

Islam, M. M., Sunny, A. R., Hossain, M. M., \& Friess, D. A. (2018). Drivers of mangrove ecosystem service change in the Sundarbans of Bangladesh. Singapore Journal of Tropical Geography, 39(2), 244-265. https://doi.org/10.1111/sjtg.12241

Islam, M. T. (2014). Sundarbans restoration: Bangladesh perspective: Capacity building workshop for central, south and east Asia on ecosystem conservation and restoration to support achievement of the Aichi biodiversity targets. Bangladesh Forest Department. Retrieved from https://www.cbd.int/doc/meetings/ecr/cbwecr-2014-07/other/cbwecr-2014-07-presentation-day4-13-en.pdf

ITTO (International Tropical Timber Organization). (2017). Report of International Conference on Sustainable Mangrove Ecosystems: Managing a vital resource for achieving the Sustainable Development Goals and the Paris Agreement. International Tropical Timber Organization, Yokohama, Japan.

Kamruzzaman, M., Ahmed, S., Paul, S., Rahman, M. M., \& Osawa, A. (2018). Stand structure and carbon storage in the oligohaline zone of the Sundarbans mangrove forest, Bangladesh. Forest Science and Technology, 14(1), 23-28. https://doi.org/10.1080/21580103.2017.1417920

Khan, N. A. (2001). Final report of Bangladesh case study. Asian Developmwnt Bank. Regional study on forest policy and institutional reform. from http://citeseerx.ist.psu.edu/viewdoc/download?doi=10.1.1.202.7382andrep=replandtype=pdf

Korhola, R. E. (2014). The rise and fall of Kyoto Protocol: Climate change as a political process. Retrieved from https://helda.helsinki.fi/bitstream/handle/10138/136507/Therisea.pdf

Langat, E. K. Maranga, A. A., \& Aboud, J. K. C. (2016). Role of Forest Resources to Local Livelihoods: The Case of East Mau Forest Ecosystem, Kenya. International Journal of Forestry Research, 10.

Mathur, H. M. (1997). Participatory development: Some areas of current concern. Sociological Bulletin, 46(1), 53- 
95. Retrieved from https://www.jstor.org/stable/23619788?seq=1\#metadata_info_tab_contents

Mazumder, M. H. M., Shamsuzzaman, M. M., Rashed-Un-Nabi, M., \& Karim, E. (2018). Social-ecological dynamics of the small-scale fisheries in Sundarban mangrove forest, Bangladesh. Aquaculture and Fisheries, 3, 38-49.

Mondal, S. H. M. (2017). Population and land cover dinamics of Sundarbans impact zone is Bangladesh. Landscape and Environment, 11(1), 1-13. https://doi.org/10.21120/le/11/1/1

Ostrom, E. (2000). Private and common property rights. In Bouckaert, B., \& De Geest, G. (Eds.), Encyclopedia of Law and Economics (pp. 332-379). Retrieved from https://www.sfu.ca/ allen/common\%20property.pdf

Ostrom, E. (2009). A general framework for analyzing sustainability of social ecological system. Science, 325(5939), 419-422. https://doi.org/10.1126/science.1172133

Payo, A., Mukhopadhyay, A., Hazra, S., Ghosh, T., Brown, S., Nichols, I. R., ... Haque, A. (2016). Projected changes in area of the Sundarban mangrove forest in Bangladesh due to SLR by 2100. Climatic Change, 139, 279-291. https://doi.org/10.1007/s10584-016-1769-z

Riddell, M. (2013). Assessing the impacts of conservation and commercial forestry on livelihoods in northern republic of Congo. Conservation and Society, 11, 199-217.

Roy, A. K. D. (2014). Determinants of participation of mangrove-dependent communities in mangrove conservation practices. Ocean and Coastal Management, $98,70-78$. https://doi.org/10.1016/j.ocecoaman.2014.06.001

Roy, A. K. D. (2016). Local community attitudes towards mangrove forest conservation: Lessons from Bangladesh. Marine Policy, 74, 186-194.

Roy, A. K. D., \& Gow, J. (2018). A critical assessment of employing democratic and deliberative ideals in the environmental planning process in Bangladesh. Journal of Environmental planning and Management, 61(14), 2590-2612. https://doi.org/10.1080/09640568.2017.1406341

Roy, A. K. D., Alam, K., \& Gow, J. (2011). A review of the role of property rights and forest policies in the management of the Sundarbans mangrove forest in Bangladesh. Forest Policy and Economics, 15, 46-59.

Roy, A. K. D., Alam, K., \& Gow, J. (2013). Community perceptions of state forest ownership and management: A case study of the Sundarbans Mangrove Forest in Bangladesh. Journal of Environmental Management, 117, 141-149.

Sabbir, H. (2012). Change detection in the forest coverage of Sundarban mangrove forest from 1989 to 2009 (Masters thesis). Department of Geography and Environment, Dhaka University. https://doi.org/10.13140/RG.2.1.3499.6321

SAHR (South Asians for Human Rights). (2015). Report of the fact-finding mission to Rampal, Bangladesh. Retrieved from https://ideas.repec.org/p/ess/wpaper/id7558.html

Salafsky, N., \& Margoluis, R. (1999). The Threat Reduction Assessment (TRA) approach to measuring conservation success: a practical and cost-elective framework for evaluating conservation and development projects. Conservation Biology, 13, 830-841.

Salafsky, N., Koebner, L., Sokolow, J. E. S., Grifo, F. T., \& Simpson, S. (1998). Community-based approaches for combining conservation and development. In Scientists on biodiversity. New York: American Museum of Natural History.

Sarker, K. S., Richard, R., Paul, K., N., \& Matthiopoulus, J. (2019). Modelling spatial biodiversity in the world' s largest mangrove ecosystem - The Bangladesh Sundarbans: A baseline for conservation. Diversity and Distributions, 25(5), 729-742. https://doi.org/10.1111/ddi.12887

Sarker, K. S., Richard, R., Thompson, J., Paul, K. N., \& Matthiopoulus, J. (2016). Are we failing to protect threatened mangroves in the Sundarbans world heritage system? Scientific Reports, 6(21234), 1-12. https://doi.org/ 10.1038/srep21234

Swapan, M. S. H., \& Gavin, M. (2011). A desert in the delta: participatory assessment of changing livelihoods induced by commercial shrimp farming in Southwest Bangladesh. Ocean and Coastal Management, 54, 45 54.

The Daily Star. (2018, July 09). Sundari disappearing fast in Sundarbans for salinity, diseases. Retrieved from https://www.thedailystar.net/environment/sundari-tree-disappearing-fast-sundarbans-salinity-various- 
diseases-1602391

Toit, T. D. (2002). Wildlife harvesting guidelines for community-based wildlife management: a southern African perspective. Biodiversity Conservation, 4, 1403-1416.

UNESCO. (2016). International day for the conservation of mangrove ecosystem, 2016. Retrieved from $\mathrm{http} / /$ www.unesco.org/new/en/unesco/events/prizes-andcelebrations/celebrations/international-days/intday-for-the-conservation-of-the-mangrove-ecosystem/mangrove-ecosystem-2016/

UNESCO. (2017). The Sundarbans: 2017 conservation outlook assessment. IUCN World Heritage Outlook. Retrieved from https://www.worldheritageoutlook.iucn.org

Valiela, I., Bowen, J. L., \& York, J. K. (2001). Mangrove forests: one of the world's threatened major tropical environments. BioScience, 51, 807-815.

WRI (World Resources Institute). (2015). Satellite data reveals state of the world's mangrove forests. Retrieved from http://www.wri.org/blog/2015/02/satellite-data-reveals-stateworld\%E2\%80\%99s-mangrove-forests

\section{Copyrights}

Copyright for this article is retained by the author(s), with first publication rights granted to the journal.

This is an open-access article distributed under the terms and conditions of the Creative Commons Attribution license (http://creativecommons.org/licenses/by/4.0/). 